\title{
PCR based detection of mycobacteria in paraffin wax embedded material routinely processed for morphological examination
}

\author{
T Frevel, K L Schäfer, M Tötsch, W Böcker, B Dockhorn-Dworniczak
}

\begin{abstract}
Background-The incidence of mycobacterial infections has increased during the past five years. A prompt diagnosis is indispensable for initiating appropriate treatment. Because culturing of mycobacteria takes three to six weeks and sensitivity of microscopic detection of acid fast bacilli is low, amplification methods provide promising possibilities. Recently, the polymerase chain reaction (PCR) has been shown to be useful for confirming a mycobacterial infection, especially in cases with unexpected histological findings or lack of suitable material for culturing.
\end{abstract}

Aims-To evaluate the impact of PCR based techniques in the detection of mycobacterial infections in uncultured routine histological specimens as an alternative to surgical pathology.

Methods-Two hundred and twenty nine formalin fixed and paraffin wax embedded samples from 141 patients with clinical or histological suspicion of a mycobacterial infection were investigated using three different PCR assays and Southern blotting. PCR results were compared with histology and culture and the patients' clinical findings.

Results-When using culture as the reference method, the sensitivity for the detection of mycobacteria of the tuberculosis complex was $90 \%$, specificity was $92 \%$, the positive predictive value was $81 \%$, and the negative predictive value was $96 \%$. The sensitivity for the detection of nontuberculous mycobacteria was $100 \%$ and specificity was $78 \%$, the positive predictive value was $26 \%$, and the negative predictive value was $100 \%$. The patients' clinical findings supported the PCR positive results, indicating a mycobacterial infection in 11 of 18 initially culture negative cases and in 21 of 35 PCR positive cases without culture results.

Conclusions-These results indicate that PCR based techniques are sensitive, specific, and rapid methods for the detection of mycobacteria in routinely processed paraffin wax embedded and formalin fixed histological samples.

(f Clin Pathol: Mol Pathol 1999;52:283-288)

Keywords: polymerase chain reaction; mycobacteria; paraffin wax embedded samples
In the past five years, the incidence of infections with mycobacteria of the tuberculosis complex and atypical mycobacteria has increased dramatically, both in industrialised and developing countries. In 1996, three million people died of tuberculosis and there were more new cases (eight million/year) than ever before. ${ }^{12}$ The main reasons for the growing epidemic of mycobacterial infections in industrialised countries are human immunodeficiency virus (HIV) infections, immigration from countries with a high prevalence of tuberculosis, immunosuppression treatments, and multidrug resistant mycobacteria. ${ }^{2}$ Rapid, specific, and sensitive methods for the detection of mycobacterial infections are essential for their diagnosis and effective treatment. Culture in liquid and solid media remains the gold standard, but it takes three to eight weeks to obtain a result, and the microscopic detection of acid fast bacilli requires large numbers of bacteria $\left(10^{4} / \mathrm{ml}\right)$ in the sample. ${ }^{3}$ Particularly in cases with unexpected histopathological suspicion of a mycobacterial infection, there is often no material left for culturing, so that diagnosis depends on a morphological examination and microscopic detection of acid fast bacilli. Therefore, the development of more rapid and reliable methods for the detection of mycobacteria is an important goal.

Hance and colleagues ${ }^{4}$ first described the polymerase chain reaction (PCR) based amplification of a $383 \mathrm{bp}$ mycobacterial DNA fragment of the $65 \mathrm{kDa}$ heat shock protein (HSP). Since then, a wide range of molecular amplification techniques has been developed for the detection of mycobacteria, including the amplification of DNA encoding mycobacterial antigens, ${ }^{5-7}$ of ribosomal RNA, ${ }^{89}$ of repetitive sequences of the Mycobacterium tuberculosis complex, ${ }^{10-13}$ and, recently, of direct repeats. ${ }^{14}$

However, in most cases respiratory specimens, liquid specimens, cultured material, or unfixed tissue samples were examined, and there are few studies on the detection of mycobacteria in paraffin wax embedded, formalin fixed specimens. ${ }^{1516}$ In our study, a combination of three different PCR assays was performed on formalin fixed and paraffin wax embedded material. A 383 bp DNA fragment ${ }^{4}$ and an internal $203 \mathrm{bp}$ DNA fragment ${ }^{17}$ of the $65 \mathrm{kDa}$ surface antigen gene common to all mycobacteria and a $123 \mathrm{bp}$ DNA fragment of the insertion sequence (IS) 6110, which is specific to mycobacteria of the tuberculosis complex, ${ }^{10}$ were amplified. 
Table 1 Primer sequences for PCR

\begin{tabular}{|c|c|c|c|c|c|}
\hline Primer & Primer sequence & Gene (product size) & $\begin{array}{l}\text { Annealing } \\
\text { temperature }\end{array}$ & $\begin{array}{l}\text { PCR } \\
\text { cycles }\end{array}$ & Reference \\
\hline$\overline{\mathrm{A} 1}$ & $\begin{array}{l}\text { 5'-GAGATCGAGCTGGAGGATCC-3' } \\
\text { sense }\end{array}$ & $\begin{array}{l}65 \mathrm{kDa} \text { heat shock } \\
\text { protein }\end{array}$ & $58^{\circ} \mathrm{C}$ & 30 & Hance and colleagues ${ }^{4}$ \\
\hline A2 & $\begin{array}{l}\text { 5'-AGCTGCAGCCCAAAGGTGTT-3' } \\
\text { antisense }\end{array}$ & Primary PCR (383 bp) & & & \\
\hline $\mathrm{B} 1$ & $\begin{array}{l}\text { 5'TAGCCAAGAAGACCGATGAC-3' } \\
\text { sense }\end{array}$ & $\begin{array}{l}65 \mathrm{kDa} \text { heat shock } \\
\text { protein }\end{array}$ & $54^{\circ} \mathrm{C}$ & 35 & Diallo and colleagues $^{17}$ \\
\hline B2 & $\begin{array}{l}\text { 5‘-AATCTGCTCCTTGGTCTCGA-3’ } \\
\text { antisense }\end{array}$ & Nested PCR (203 bp) & & & \\
\hline $\mathrm{C} 1$ & $\begin{array}{l}\text { 5'-CCTGCGAGCGTAGGCGTCGG-3' } \\
\text { sense }\end{array}$ & IS $6110(123 \mathrm{bp})$ & $58^{\circ} \mathrm{C}$ & 35 & Eisenach and colleagues $^{10}$ \\
\hline $\mathrm{C} 2$ & $\begin{array}{l}\text { 5'-CTCGTCCAGCGCCGCTTCGG-3' } \\
\text { antisense }\end{array}$ & & & & \\
\hline D1 & $\begin{array}{l}\text { 5'-CAACTTCATCCACGTTCACC-3' } \\
\text { sense }\end{array}$ & $\beta$ globin (268 bp) & $58^{\circ} \mathrm{C}$ & 20 & Bauer and colleagues ${ }^{20}$ \\
\hline $\mathrm{D} 2$ & $\begin{array}{l}\text { 5'-GAAGAGCCAAGGACAGGTAC-3' } \\
\text { antisense }\end{array}$ & & & & \\
\hline
\end{tabular}

Since 1992, the PCR based detection of mycobacteria has been firmly established as a diagnostic tool in the routine investigation of histopathological samples suspected of mycobacterial infections at the Gerhard-Domagk Institute of Pathology at the University of Münster.

In our study, a retrospective evaluation of routinely processed cases was performed comparing PCR results with the histological features and clinical data. All 229 samples were derived from routine histomorphological examinations carried out at the institute from 1992 to 1995.

\section{Materials and methods}

MATERIALS

Two hundred and twenty nine formalin fixed, paraffin wax embedded samples from 141 patients who, either for clinical $(51 \%)$ or histological (49\%) reasons, were suspected of mycobacterial infection were examined by PCR and Southern blotting. All samples had been processed routinely for morphological examination between 1992 and 1995 at the Gerhard-Domagk Institute of Pathology. For routine histology, samples were stained with haematoxylin and eosin, and with ZiehlNeelsen for microscopic identification of acid fast bacilli. The results of the microbiological examination of 93 samples taken from 76 patients were available for our study. The samples contained 81 pulmonary and 148 extrapulmonary specimens. The pulmonary samples consisted of 40 bronchus biopsies, 36 bronchoalveolar lavages, and five sputum specimens. The extrapulmonary samples included 45 lymph nodes, 42 skin tissues, 13 samples of the gastrointestinal tract, 11 samples of the nasopharynx and cavity of the mouth, nine bone biopsies, seven samples of the urogenital tract, six abscess punctates, and 15 miscellaneous specimens.

\section{METHODS}

\section{Sample preparation for PCR}

Formalin fixed, paraffin wax embedded material was cut into $5 \mu \mathrm{m}$ sections, mounted on glass slides, and dewaxed with xylene. After removing the solvent in a decreasing series of alcohol (99-50\% alcohol content), ${ }^{18}$ the sample was rehydrated with distilled water and removed from the glass slides with $100 \mu \mathrm{l}$ digestion buffer $(200 \mu \mathrm{g} / \mathrm{ml}$ proteinase $\mathrm{K}$, $50 \mathrm{mM}$ Tris/ $\mathrm{HCl}, \mathrm{pH} 8.5,1 \mathrm{mM}$ ethylenediaminetetraacetic acid, and $0.5 \%$ Tween 20 ). The mixture was incubated at $56^{\circ} \mathrm{C}$ overnight, followed by inactivation of proteinase $\mathrm{K}$ at $94^{\circ} \mathrm{C}$ for 10 minutes. After the digestion procedure, the sample was submitted to PCR without further purification to prevent loss of DNA.

\section{Primers}

Four sets of primers were used for each sample (table 1). Primers A1 and A2 are specific for a $383 \mathrm{bp}$ segment of a $65 \mathrm{kDa}$ mycobacterial surface antigen gene common to all mycobacterial species. ${ }^{419}$ To increase the sensitivity, internal primers B1 and B2 encoding a $203 \mathrm{bp}$ segment within the $383 \mathrm{bp}$ fragment were chosen. ${ }^{17}$ A $123 \mathrm{bp}$ fragment of the repetitive insertion element IS 6110, which is specific to the $M$ tuberculosis complex, was amplified using primers $\mathrm{C} 1$ and $\mathrm{C} 2 .^{10}$ The amplification of a $268 \mathrm{bp}$ fragment of the human $\beta$ globin gene with the primers D1 and D2 was performed in all samples to test for inhibition and to confirm the suitability of the material for PCR. ${ }^{20}$

\section{Amplification by PCR}

The PCR was modified according to the standard protocol of Mullis and Faloona. ${ }^{21}$ The reaction mixtures with a final volume of $20 \mu \mathrm{l}$ included $0.3,1.0$, and $3.0 \mu \mathrm{l}$, respectively, of the digested material, $10 \mathrm{mM}$ Tris/ $\mathrm{HCl}$ (pH 8.3), $50 \mathrm{mM} \mathrm{KCl,} 1.5 \mathrm{mM} \mathrm{MgCl}_{2}$, $0.2 \mathrm{mM}$ of each deoxynucleotide trisphosphate, 0.5 U Taq polymerase (AmpliTaq ${ }^{\circledR}$; Perkin Elmer, Branchburg, New Jersey, USA) and, depending on the amplified fragment, $0.4 \mathrm{pmol} / \mu \mathrm{l}$ of primer pair $\mathrm{A}$ and $0.2 \mathrm{pmol} / \mu \mathrm{l}$ of primer pairs B, C, and D. After an initial denaturation step at $94^{\circ} \mathrm{C}$ for four minutes, amplification was performed under the following conditions. Each cycle consisted of denaturation at $94^{\circ} \mathrm{C}$ for 30 seconds and primer extension at $72^{\circ} \mathrm{C}$ for 90 seconds. In the first five cycles, the annealing temperature of the primer pairs $\mathrm{A}$, $\mathrm{C}$, and $\mathrm{D}$ was decreased by $1^{\circ} \mathrm{C}$ every cycle, from $64^{\circ} \mathrm{C}$ to $61^{\circ} \mathrm{C}$, and was followed by 30 cycles for the primer pairs $\mathrm{C}$ and $\mathrm{D}$ and 35 cycles for the primer pair $\mathrm{A}$, with an annealing temperature of $58^{\circ} \mathrm{C}$. In the first nine cycles, 
the annealing temperature of the primer pair $\mathrm{B}$ was decreased by $1^{\circ} \mathrm{C}$ every third cycle, from $57^{\circ} \mathrm{C}$ to $55^{\circ} \mathrm{C}$, and followed by an annealing temperature of $54^{\circ} \mathrm{C}$ for 20 cycles.

Detection of PCR products

To detect the amplified PCR products, $2.5 \mu \mathrm{l}$ of the reaction mixture was separated electrophoretically on $12 \%$ polyacrylamide gels (Gel-
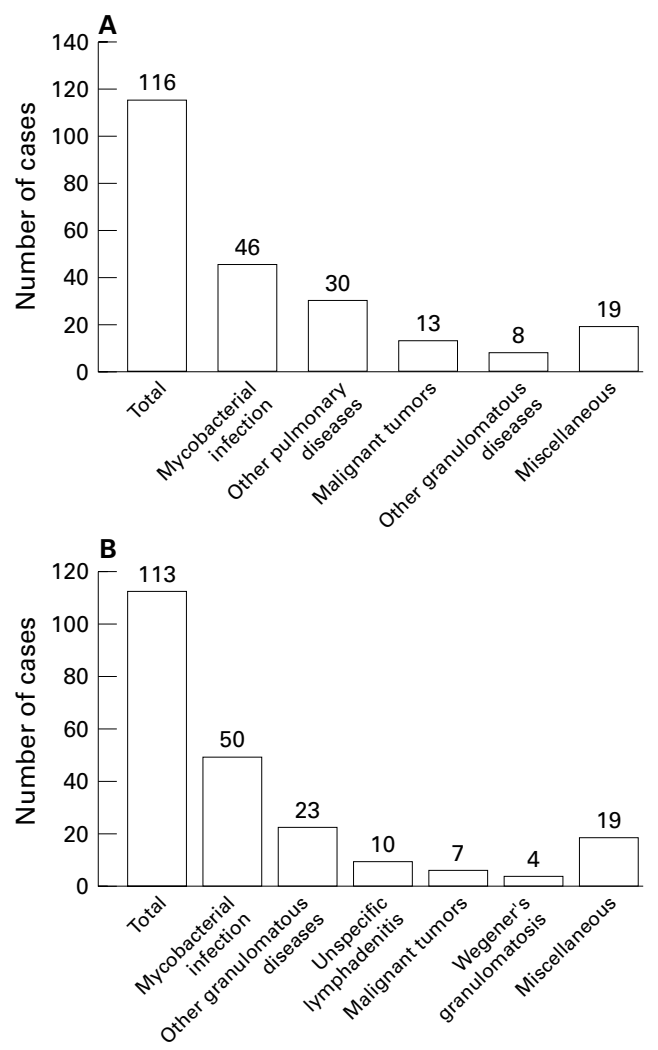

Figure 1 (A) Diagnosis on discharge from hospital of samples with clinical suspicion of a mycobacterial infection on admission to routine pathology. (B) Diagnosis on discharge from hospital of samples with histological suspicion of tuberculosis on admission to routine pathology.

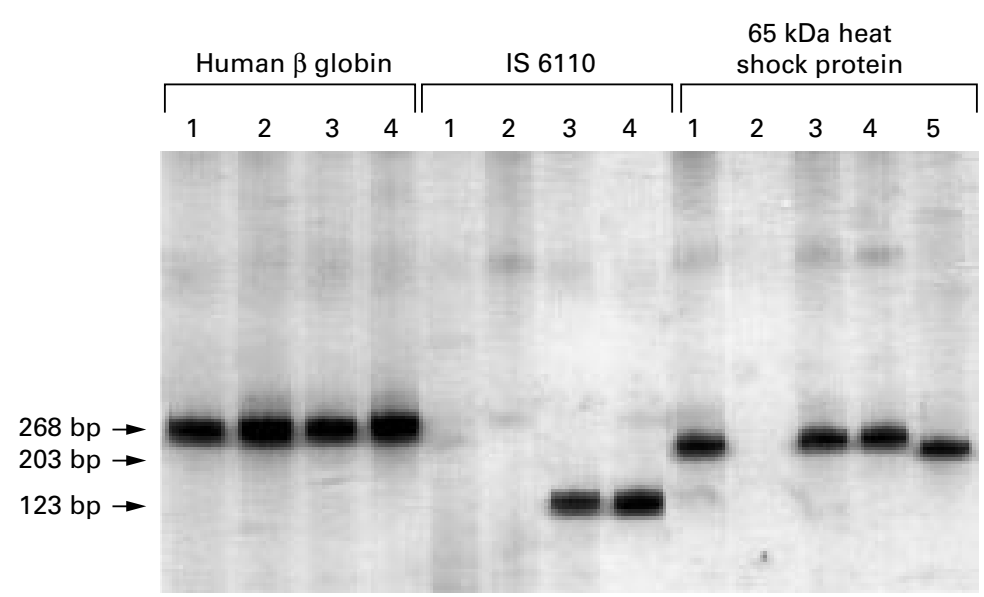

Figure 2 Detection of mycobacterial PCR products, $12 \%$ native polyacrylamide gel electrophoresis, silver stained. PCR assays were performed on formalin fixed and paraffin wax embedded lymph nodes from three patients (cases 1-3). Non-tuberculous mycobacterial infection (case 1): detection of $203 \mathrm{bp}$ PCR fragments and no amplification of $123 \mathrm{bp}$ fragments of IS 6110. Mycobacterium tuberculosis complex infection (case 3): detection of fragments of the $65 \mathrm{kDa}$ heat shock protein gene and additional amplification of $123 \mathrm{bp}$ PCR products of IS 6110. No evidence of mycobacterial infection (case 2): no amplification of either 203 bp PCR fragments or 123 bp PCR fragments. The suitability of the material was confirmed by amplification of 268 bp fragments of the human $\beta$ globin gene.
Bond $^{\circledR}$-PAG; Bio Products, Rockland, USA) using a thermostatically controlled horizontal electrophoresis system (Pharmacia LKB Multiphor II; Pharmacia, Uppsala, Sweden) and visualised by silver staining. ${ }^{22}$

\section{Southern blotting}

The specificity of PCR products was confirmed by Southern blotting, particularly when the PCR amplification products were weak. Negative results in Southern blotting were omitted from the study. PCR products of $123 \mathrm{bp}$, specific to the $M$ tuberculosis complex, and $203 \mathrm{bp}$ PCR products, common to all mycobacteria, were digoxigenin labelled and used as probes.

Aliquots of $3 \mu \mathrm{l}$ of amplified PCR products were separated electrophoretically on $1 \%$ agarose gels containing $20 \mu \mathrm{l}$ ethidium bromide and visualised by UV transillumination. The DNA was denaturated by $\mathrm{NaOH}$ and blotted on to nylon membranes (Boehringer, Mannheim, Germany). After prehybridisation ( $5 \times$ saline sodium citrate (SSC), $0.1 \% N$-lauroylsarcosine, $0.02 \%$ sodium dodecyl sulphate (SDS), $1 \%$ blocking reagent) at $68^{\circ} \mathrm{C}$ for one hour, hybridisation with digoxygenin labelled probes was performed at $68^{\circ} \mathrm{C}$ overnight. Membranes were washed twice with $200 \mathrm{ml}$ wash solution containing $20 \mathrm{ml} \mathrm{SSC}$ and $2 \mathrm{ml} 0.1 \%$ SDS at room temperature for five minutes and at $65^{\circ} \mathrm{C}$ for 15 minutes. For chemiluminescent detection, antidigoxygenin-alkaline phosphatase (AP) (Boehringer, Mannheim, Germany) was applied, with CSPD as substrate, and membranes were exposed to Kodak scientific imaging film XAR 5 at room temperature for 10-15 minutes

\section{Controls}

Each PCR run included positive and negative controls. The positive controls consisted of DNA extracted from cultures of the $M$ tuberculosis and $M$ avium complexes and a sample of a patient with culture confirmed $M$ tuberculosis infection. The negative controls contained the reaction mixture without DNA, which was replaced by the equivalent volume of distilled water.

\section{Results}

All the 229 samples were derived from routine histopathological examinations from 1992 to 1995 and belonged to two groups. In 116 of the 229 cases $(51 \%)$, tuberculosis had been clinically suspected at the time when samples were taken for histopathological examination. In the remaining 113 cases (49\%), an unexpected mycobacterial infection had been detected by histology. Figure $1 \mathrm{~A}$ and $\mathrm{B}$ shows diagnoses on discharge from hospital of samples with initial clinical suspicion of mycobacterial infection and of samples with initial histological suspicion of tuberculosis on admission to routine pathology.

All 229 samples were analysed by PCR. Figure 2 shows a silver stained polyacrylamide gel with electrophoretic separation of amplified mycobacterial DNA from three specimens. Figure 3 shows an example of a Southern blot experiment to confirm specificity of a PCR 


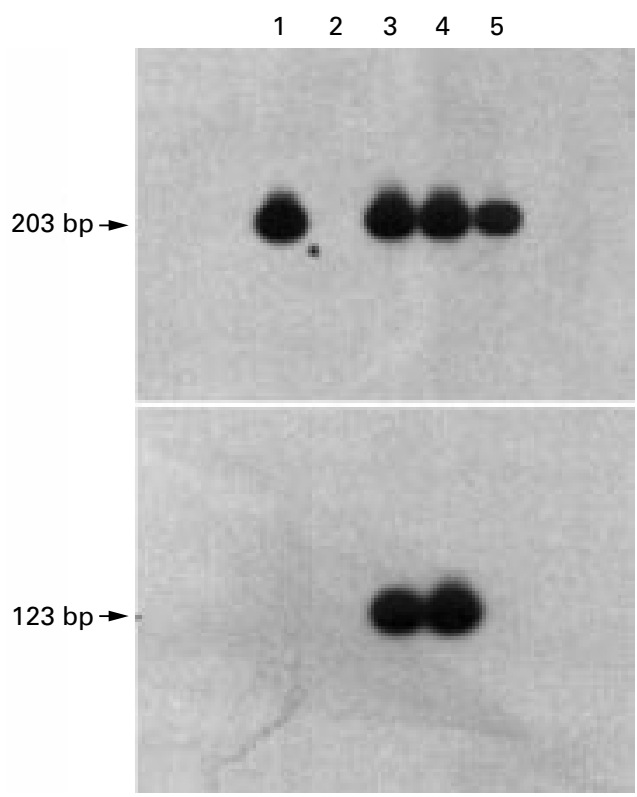

Figure 3 Non-radioactive Southern blot. The specificity of the PCR products obtained from case 1 and case 3 was confirmed by Southern blotting. The probe corresponding to $203 \mathrm{bp}$ fragments of the $65 \mathrm{kDa}$ heat shock protein gene resulting in signals in both cases, whereas positivity with the $123 \mathrm{bp}$ probe was found only in case 3 , indicating an infection with mycobacteria of the tuberculosis complex.

product. Nineteen samples lacking amplification of the $\beta$ globin fragment were not suitable for PCR. In 93 cases, microbiological data from cultures were available. Fifty of those 93 samples were cultured both for the $M$ tuberculosis complex and non-tuberculous mycobacteria. The remaining 117 samples were formalin fixed and paraffin wax embedded without further microbiological examination. Clinical findings, treatment results, and follow up data were available from all patients so that they could be compared with the PCR results. Tables 2 and 3 show all the PCR results in correlation with culture results.

Table 2 Results of PCR amplification of $123 \mathrm{bp} D N A$ sequences of IS 6110 in mycobacteria of the tuberculosis complex (contingency table)

\begin{tabular}{lllll}
\hline \multirow{4}{*}{ PCR } & \multicolumn{2}{l}{ Culture results } & & \\
\cline { 2 - 3 } & Positive & Negative & Not cultured & Total \\
\hline Positive & 18 & 4 & 13 & 35 \\
Negative & 2 & 50 & 82 & 134 \\
Total & 20 & 54 & 95 & 169 \\
\hline
\end{tabular}

Sensitivity, $90 \%$ (18 of 20); specificity, $92 \%$ (50 of 54); positive predictive value, $81 \%$ (18 of 22 ); negative predictive value, $96 \%$ (50 of 52).

Table 3 Results of amplification of DNA fragments of the $65 \mathrm{kDa}$ heat shock protein gene by nested PCR in non-tuberculous mycobacteria (contingency table)

\begin{tabular}{lllll}
\hline \multirow{4}{*}{ PCR } & \multicolumn{2}{l}{ Culture results } & \\
\cline { 2 - 3 } & Positive & Negative & Not cultured & Total \\
\hline Positive & 5 & 14 & 22 & 41 \\
Negative & 0 & 50 & 82 & 132 \\
Total & 5 & 64 & 104 & 173 \\
\hline
\end{tabular}

Sensitivity, $100 \%$ (5 of 5); specificity, $78 \%$ (50 of 64 ); positive predictive value, $26 \%$ ( 5 of 19); negative predictive value, $100 \%$ (50 of 50).
PCR results were positive in 18 of 20 cases with culture confirmed $M$ tuberculosis infection. The remaining two culture positive samples, a lymph node and a bone biopsy, were PCR negative.

The mycobacterial cultures were negative in 54 specimens, including 11 cases with strong clinical suspicion of tuberculosis. In 50 of these samples, PCR results were negative. In the remaining four culture negative cases, fragments of the $M$ tuberculosis complex could be amplified by PCR and confirmed by Southern blotting. The clinical data of these samples taken from four patients confirmed the suspicion of tuberculosis. Two of those patients who were HIV positive received tuberculostatic treatment, whereas the other two patients were not treated because of their culture negative results. The diagnoses on discharge from hospital of these two patients were bronchial carcinoma and skin sarcoidosis. Further investigations confirmed a squamous non-small cell carcinoma of the right upper lobe in the first patient and extrapulmonary features of sarcoidosis of skin, eyes, liver, and spleen in the second patient.

In all five samples with culture confirmed infections with non-tuberculous mycobacteria, the $383 \mathrm{bp}$ and $203 \mathrm{bp}$ fragments were detected by PCR. The clinical data confirmed an infection with the $M$ avium complex in samples from two HIV positive patients.

Fifty of 64 specimens with a culture negative result for non-tuberculous mycobacteria were also PCR negative. In the remaining 14 culture negative cases, DNA fragments of nontuberculous mycobacteria could be amplified by PCR. These 14 samples were from 14 different patients and consisted of eight bronchoalveolar lavages, three skin specimens, one lymph node, one liver biopsy, and one abscess punctate. In nine of these patients, an infection with atypical mycobacteria was clinically confirmed and treated successfully. The remaining five patients did not show any clinical signs of a mycobacterial infection. Three of the samples were bronchoalveolar lavages and one sample was a skin biopsy from a patient who had been treated for cutaneous tuberculosis for six months. One skin specimen came from a patient with a papulonecrotic tuberculid, yet no infectious tuberculosis has been found.

One hundred and seventeen of the initially formalin fixed and paraffin wax embedded samples could not be analysed by culture, but were suitable for PCR. Eighty two of these samples were PCR negative. In all the remaining 35 samples, DNA fragments of the gene encoding the $65 \mathrm{kDa}$ HSP were amplified. In addition, DNA fragments specific to the $M$ tuberculosis complex were detected by PCR in 13 of these 35 specimens. All PCR results of the 117 uncultured samples were compared with the clinical data and the histopathological findings.

In 10 of 13 uncultured samples with PCR positive results for the $M$ tuberculosis complex, tuberculosis was suspected during the further assessment of the course of diseases, resulting 
in tuberculostatic treatment in all 10 patients. For the remaining three samples, the diagnoses on discharge were bronchial carcinoma in two samples from one patient and Hodgkin's disease in another sample.

An infection with atypical mycobacteria was confirmed in the clinical data of 11 of the 22 uncultured samples that had been PCR positive for non-tuberculous mycobacteria. Five samples came from patients who were immunocompromised as a result either of HIV infections (three patients) or cyclosporin A treatment after heart and renal transplantation (one patient each). All 11 cases were treated successfully with tuberculostatic treatment. An infection with non-tuberculous mycobacteria could not be clinically diagnosed in the remaining 11 cases, although in four of these samples histopathology revealed an infection with atypical mycobacteria. Two specimens came from two patients who were immunocompromised as a result of cyclosporin $\mathrm{A}$ treatment.

The contingency tables 2 and 3 show that when culture was used as the reference method for PCR, sensitivity for the detection of the $M$ tuberculosis complex by amplification of DNA fragments of IS 6110 was $90 \%$ (18 of 20) and specificity $92 \%$ (50 of 54 ). The positive predictive value was $81 \%(18$ of 22$)$ and the negative predictive value was $96 \%$ (50 of 52). Sensitivity for the detection of non-tuberculous mycobacteria by nested PCR amplifying DNA sequences of the $65 \mathrm{kDa}$ HSP gene was $100 \%$ (five of five) and specificity $78 \%$ (50 of 64 ). The related positive predictive value was $26 \%$ (five of 19) and the negative predictive value was $100 \%$ (50 of 50 ).

\section{Discussion}

Tuberculosis had been the clinical differential diagnosis in only $51 \%$ (116 samples) of the cases submitted to routine histopathological examination. In $49 \%$ (113 samples) of the cases, mycobacterial infections had been found unexpectedly by histology. Before admission to routine pathology, these samples had been clinically suspected to be carcinomas, malignant lymphomas, sarcoidosis, or cervical masses with unknown causes. Hence, there was often no material left for mycobacterial culturing. Because microscopic detection of acid fast bacilli by Ziehl-Neelsen staining is often insufficiently sensitive and specific to confirm a histopathological diagnosis, we introduced PCR based techniques, which have become increasingly valuable for the identification of mycobacteria in tissue routinely processed for histopathological examination.

In our study, 229 formalin fixed and paraffin wax embedded samples were analysed by PCR and Southern blotting. Internal control by PCR amplification of the human $\beta$ globin gene revealed a failure of PCR in 19 samples (8\%). All 117 samples without culture information were suitable for PCR. PCR was inhibited in 19 samples. As Chan et al have reported previously, inhibitors were detected more frequently in extrapulmonary than in pulmonary specimens. ${ }^{23}$ PCR inhibition might be caused by degradation of DNA by formalin fixation ${ }^{24} 25$ of tissue samples and acid decalcification methods for bone biopsies. However, the suitability of $91 \%$ of the routinely processed material provides an encouraging basis for molecular genetic analysis.

Mycobacteria of the tuberculosis complex were detected by PCR in 18 of 20 culture positive samples. The two PCR negative samples comprised a bone biopsy and a lymph node. Such a negative PCR result might be attributed to several conditions. As shown for lymph nodes, non-homogenous distribution of mycobacteria results in sections without bacteria. ${ }^{26}$ Therefore, in many cases a positive result cannot be attained unless additional sections are analysed. Furthermore, the feasibility of PCR might be hampered by tissue type. In particular, bone specimens (as in the second negative case) are often difficult to process for DNA extraction.

In 50 of 54 cases, PCR results corresponded with negative cultures. The clinical data of the four PCR positive cases confirmed the suspicion of tuberculosis in two HIV positive patients, thus initiating successful tuberculostatic treatment.

The remaining two patients were not treated because of negative cultures and a diagnosis of bronchial carcinoma in one patient and skin sarcoidosis in the other. Positive PCR results in combination with negative cultures in patients with carcinoma have been described previously. ${ }^{27}{ }^{28}$ Mycobacterial DNA might be released from the destroyed tissue. ${ }^{27}$ In this case, DNA of non-viable mycobacteria could have been amplified, yielding positive PCR results and negative cultures. The detection of mycobacterial DNA by PCR in culture negative cases with sarcoidosis has been reported previously and it has been suggested that mycobacteria might be involved in the pathogenesis of sarcoidosis. ${ }^{29-31}$ Popper et al suggested that cell wall defective mycobacteria or persistent intracellular DNA from mycobacteria might be the causual agent in some cases of sarcoidosis. $^{32}$

Although there is compelling evidence that amplification methods are more sensitive than culture, ${ }^{27}$ especially in extrapulmonary specimens, ${ }^{33}$ culture is still the gold standard.

Therefore, culture was used as the reference method for the sensitivity of PCR, the detection of the $M$ tuberculosis complex being $90 \%$ and the corresponding specificity $92 \%$.

Culture negative results for atypical mycobacteria corresponded to negative PCR results in 50 of 64 cases, whereas 14 samples were PCR positive for the detection of nontuberculous mycobacteria. An infection with atypical mycobacteria had been clinically diagnosed and treated with antituberculosis drugs in nine of these 14 patients. The remaining five patients showed no clinical findings indicative of an infectious mycobacteriosis. One of the five patients had been treated for a cutaneous tuberculosis. During tuberculostatic treatment, PCR results often remain positive for several weeks after cultures become negative, which is why amplification of non-viable mycobacteria 
could explain the positive PCR result in this sample. On the other hand, mycobacteria in treated tuberculosis may remain viable, even though their growth is inhibited on culture media, whereas mycobacterial DNA sequences continue to be amplified by PCR.

Another patient had a papulonecrotic tuberculid. Degitz reported that mycobacteria might not be cultured from tuberculoids because they do not grow in these lesions, whereas their DNA may still be detected by PCR. ${ }^{34}$

Eight of the 14 samples with positive PCR results for non-tuberculous mycobacteria in combination with negative cultures were bronchoalveolar lavages. The most likely explanation for these results is that because of the high sensitivity of amplification methods, even small numbers of mycobacteria are detectable by PCR. It has also been reported that contamination of bronchoscopes with mycobacteria of the tuberculosis complex and non-tuberculous mycobacteria could lead to positive PCR results. ${ }^{35} 36$

Using culture as a reference method the sensitivity for the detection of non-tuberculous mycobacteria by PCR was $100 \%$. The corresponding specificity of $78 \%$ might be explained by the difficulty in culturing non-tuberculous mycobacteria.

In summary, the patients'clinical charts supported the diagnosis of mycobacterial infections in 11 of 18 initially PCR positive results with negative cultures and in 21 of the 35 PCR positive cases without cultures.

Culturing 117 samples was impossible, either because of a lack of suitable material or unexpected histopathological diagnoses. The detection of mycobacteria by PCR in these samples was useful in confirming a histological or clinical diagnosis. In 55 of 229 samples $(24 \%)$ processed routinely for morphological examination, mycobacterial infections were detected by PCR, 55\% of which were caused by the $M$ tuberculosis complex and $45 \%$ by non-tuberculous mycobacteria. Especially in cases with unexpected histological findings and no suitable material left for culturing, PCR was helpful for confirming a mycobacterial infection. Therefore, in combination with clinical findings, PCR could be of great value for initiating appropriate treatment.

1 Groups at risk, WHO report on the tuberculosis epidemic 1996. Geneva: World Health Oganisation, 1996.

2 Treatment of tuberculosis, guidelines for national programmes. Geneva: World Health Organisation, 1995.

3 Bannister BA, Begg TN, Gillespie SH. Tuberculosis and other mycobacterial diseases. In: Infectious diseases, $1 \mathrm{st}$ ed. Oxford: Blackwell Science, 1996:342-66.

4 Hance A, Grandchamp B, Levy-Frebauit V, et al. Detection and identification of mycobacteria by amplification of mycobacterial DNA. Mol Microbiol 1989;3:843-9.

5 Shankar P, Manjunath N, Lakshmi R, et al. Identification of Mycobacterium tuberculosis by polymerase chain reaction. Lancet 1990;335:423.

6 Manjunath N, Shankar P, Rajan L, et al. Evaluation of a polymerase chain reaction for the diagnosis of tuberculosis. polymerase chain reacte

7 Sjöbring U, Mecklenburg M, Andersen AB, et al. Polymerase chain reaction for the detection of Mycobacterium tuberculosis. F Clin Microbiol 1990;28:2200-4.
8 Jonas V, Alden MJ, Curry JI, et al. Detection and identification of Mycobacterium tuberculosis directly from sputum sediments by amplification of rRNA. F Clin Microbiol 1993; 31:2410-16.

9 Boddinghaus B, Rogall T, Flohr T, et al. Detection and identification of mycobacteria by amplification of rRNA. $\mathcal{F}$ Clin Microbiol 1990;28:1751-9.

10 Eisenach KD, Cave MD, Bates JH, et al. Polymerase chain reaction amplification of a repetitive DNA sequence specific for Mycobacterium tuberculosis. F Infect Dis 1990; 161:977-81.

11 Thierry D, Brisson-Noel A, Vincent-Levy-Frebault V, et al. Characterization of a Mycobacterium tuberculosis insertion sequence, IS 6110, and its application in diagnosis. $\mathcal{f}$ Clin Microbiol 1990;28:2668-73.

12 Hermans PW, Schuitema AR, Van Soolingen D, et al. Specific detection of Mycobacterium tuberculosis complex cific detection of Mycobacterium tuberculosis complex
strains by polymerase chain reaction. $\mathcal{F}$ Clin Microbiol 1990 ;

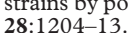

13 De Wit D, Steyn L, Shoemaker S, et al. Direct detection of Mycobacterium tuberculosis in clinical specimens by DNA amplification. I Clin Microbiol 1990;28:2437-41.

14 Beggs ML, Cave MD, Marlowe C, et al. Characterization of Mycobacterium tuberculosis complex direct repeat sequence for use in cycling probe reaction. $\mathcal{F}$ Clin Microbiol 1996;34:2985-9.

15 Vago L, Barberis M, Gori A, et al. Nested polymerase chain reaction for Mycobacterium tuberculosis IS 6110 sequence on formalin-fixed paraffin-embedded tissues with granulomatous diseases for rapid diagnosis of tuberculosis. Am $\mathcal{F}$ Clin Pathol 1998;109:411-15

16 Osaki M, Adachi H, Gomyo Y, et al. Detection of mycobacterial DNA in formalin-fixed, paraffin-embedded tissue specimens by duplex polymerase chain reaction: application to histopathologic diagnosis. Mod Pathol 1997;10:7883.

17 Diallo R, Frevel T, Poremba C, et al. Tuberculous mastitis in a patient with lupus vulgaris. Pathologe 1997;18:67-70.

8 Tötsch M, Schmid KW, Brömmelkamp E, et al. Rapid detection of mycobacterial DNA in clinical samples by multiplex PCR. Diagn Mol Pathol 1994;3:260-4.

19 Shinnick TM. The 65-kilodalton antigen of Mycobacterium tuberculosis. F Bacteriol 1987;169:1080-8.

20 Bauer HM, Ting Y, Greer CE, et al. Genital human papillomavirus infection in female university students as determined by a PCR-based method. fAMA 1991;265:472-7.

21 Mullis KB, Faloona FA. Specific syntheses of DNA in vitro via a polymerase catalyzed chain reaction. Methods Enzymol via a polymerase catal

22 Goldman D, Merril CR. Silver staining of DNA in polyacrylamide gels: linearity and effect of fragment size. Electrophoresis 1982;3:24-6.

23 Chan CM, Yuen KY, Chan KS, et al. Single-tube nested PCR in the diagnosis of tuberculosis. F Clin Pathol 1996;49: 290-4.

24 Rish JA, Eisenach KD, Cave D, et al. Polymerase chain reaction detection of Mycobacterium tuberculosis in formalinfixed tissue. Am f Respir Crit Care Med 1996;153:1419-23.

25 Wiegand P, Domhöver J, Brinkmann B. DNA degradation in formalin-fixed tissues. Pathologe 1996;17:451-4.

26 Tötsch M, Böcker W, Brömmelkamp E, et al. Diagnostic value of different PCR assays for the detection of mycobacterial DNA in granulomatous lymphadenopathy. $\mathcal{F}$ Pathol $1996 \cdot 178: 221-6$.

27 Savic B, Sjöbring U, Alugupalli S, et al. Evaluation of polymerase chain reaction, tuberculostearic acid analysis, and direct microscopy for the detection of Mycobacterium tuberculosis in sputum. F Infect Dis 1992;166:1177-80.

28 Brisson-Noel A, Nguyen S, Bonete R, et al. Diagnosis of tuberculosis by DNA amplification in clinical practice evaluation. Lancet 1991;338:364-6.

29 Fiedler HM, Rook GA, Johnson NM, et al. Mycobacterium tuberculosis DNA in tissue affected by sarcoidosis. BMF 1993;306:546-9.

30 Saboor SA, Johnson NM, McFadden J. Detection of mycobacterial DNA in sarcoidosis and tuberculosis with polymerase chain reaction. Lancet 1992;339:1012-15.

31 Popper HH, Klemen H, Hoefler G, et al. Presence of mycobacterial DNA in sarcoidosis. Hum Pathol 1997;28:796800.

32 Popper HH, Winter E, Hofler G. DNA of Mycobacterium tuberculosis in formalin-fixed, paraffin-embedded tissue in tuberculosis and sarcoidosis detected by polymerase chain reaction. Am f Clin Pathol 1994;101:738-41.

33 Noordhoek GT, Kaan JA, Mulder S, et al. Routine application of the polymerase chain reaction for detection of Mycobacterium tuberculosis in clinical samples. $\mathcal{F}$ Clin Pathol 1995;48:810-14.

34 Degitz K. Detection of mycobacterial DNA in the skin. Arch Dermatol 1996;132:71-5.

35 Reeves DS, Brown NM. Mycobacterial contamination of fibreoptic bronchoscopes. F Hosp Infect 1995;30(suppl): $531-6$.

36 Spach DH, Silverstein FE, Stamm WE. Transmission of infection by gastrointestinal endoscopy and bronchoscopy. Ann Intern Med 1993;118:117-28. 